\title{
Pengaruh Fungi Mikoriza Arbuskular Spesifik Lokal dan Kompos Terhadap Hasil Tanaman Jagung ( Zea mays L.) pada Tanah Marginal Ultisol
}

\author{
Efffect Of Specific Local Arbuscular Mycorrhizas Fungi and Compost Towards Corn \\ (Zea mays L.) On Marginal Land Ultisol
}

\author{
Fatayatinur $^{1}$, Nanda Mayani ${ }^{2}$, Teti Arabia ${ }^{2 *}$ \\ ${ }^{1}$ Program Studi Agroteknologi, Fakultas Pertanian, Universitas Syiah Kuala \\ ${ }^{2}$ Program Studi Ilmu Tanah, Fakultas Pertanian, Universitas Syiah Kuala
}

\begin{abstract}
Penelitian ini bertujuan untuk mengetahui pengaruh pemberian jenis mikoriza arbuskular spesifik lokal dan kompos serta interaksinya terhadap pertumbuhan dan hasil tanaman jagung pada tanah marginal Ultisol. Penelitian ini berlangsung dari bulan Juni hingga Oktober 2016, di Rumah Kasa Fakultas Pertanian Universitas Syiah Kuala. Penelitian ini menggunakan Rancangan Acak Kelompok pola faktorial dengan sembilan kombinasi perlakuan dan tiga ulangan, sehingga diperoleh 27 satuan percobaan. Faktor yang diteliti yaitu pemberian jenis mikoriza arbuskular (FMA) yang terdiri dari tiga taraf yaitu: tanpa FMA, Glomus sp. dan Acoulospora sp. sedangkan dosis kompos dengan tiga taraf yaitu: tanpa kompos, $25 \mathrm{~g} \mathrm{pot}^{-1}, 50 \mathrm{~g} \mathrm{pot}^{-1}$. Peubah yang diamati dalam penelitian ini jumlah biji per tongkol, berat biji kering per tongkol, berat 100 butir biji kering, dan hasil per hektar. Hasil penelitian menunjukkan bahwa perlakuan baik pemberian jenis mikoriza arbuskular (FMA) dan dosis kompos tidak berpengaruh nyata terhadap jumlah biji per tongkol, berat biji kering per tongkol, berat 100 butir biji kering dan hasil per hektar. Terdapat interaksi yang sangat nyata antara perlakuan pemberian jenis FMA dengan dosis kompos terhadap hasil per hektar serta berpengaruh nyata terhadap berat biji kering per tongkol.
\end{abstract}

Kata kunci: Jagung, FMA, kompos, ultisol.

Abstract. The aim of this research was to obtain information about the effect of local and compost specification arbuscular mycorrhizal fungi distribution and the relation towards the growth and result of corn crops on the ultisol marginal land. This research was conducted at Greenhouse of Agriculture Faculty Syiah Kuala University, from June to October 2016. This research used factorial pattern of Cluster Random Plan with nine combinations of treatment and three repetition, thus, 27 attempt of experimentation was obtained. The factors which were inspected in this research are the distribution of arbuscular mycorrhizal fungi which consist of three categories; without arbuscular mycorrhizal fungi, Glomus sp., and Acoulospora sp. while the dosage of compost in three categories; without compost, $25 \mathrm{~g}$ pot, $50 \mathrm{~g}$ pot. The variables which are observed in this research are the number of corn kernels, the weight of corn kernels per corncob, the weight of 100 dried seeds and the yields of corn crop per hectare. The result of the research conclude that the distribution of abuscular mycorrhiza fungi and the dose of compost this treatment did not have real effect on the height of the number of corn kernels per cob, the weight of dried seeds per corncob, the weight of 100 dried seeds, and the yields of corn crop per hectare. There are relation between the distribution of AMF treatment and the dosage of the compost to the length the yields of the corn crop per hectare, and also have a real effect on weight of dried seeds per corncob

Keywords: Corn, AMF, compost, ultisol

\section{PENDAHULUAN}

Jagung (Zea mays L.) merupakan sumber karbohidrat serta komoditas pangan kedua setelah padi. Komoditas ini selain digunakan sebagai kebutuhan pangan juga digunakan sebagai bahan baku pakan ternak dan industri makanan. Menurut data BPS (2016), produksi jagung tahun 2015 sebesar 205.125 ton pipilan kering, mengalami peningkatan sebanyak 2.807 ton (1.39 persen) dibandingkan tahun 2014.

$2^{2 *}$ Corresponding author: tetiarabia.agt@gmail.com 
Kebutuhan jagung sejak beberapa tahun ini terus meningkat, Pada saat ini kemungkinan perluasan areal produksi jagung terbesar adalah pada lahan kering diluar pulau Jawa (Hidayat dan Mulyani, 2002). Tanah Ultisol merupakan bagian terluas dari lahan kering di Indonesia yaitu sekitar 51 juta ha (lebih kurang 29\% luas daratan Indonesia). Forth (1991), menjelaskan bahwa tanah Ultisol merupakan tanah marginal yang memiliki sifat fisik dan kimia yang miskin unsur hara dan permeabilitas serta daya tahan air yang rendah sehingga mengakibatkan ketersediaan air berkurang.

Kendala utama tanah Ultisol sebagai lahan budidaya adalah reaksi tanah yang masam, kejenuhan basa rendah, kadar alumunium ( $\mathrm{Al}$ ) dan besi (Fe) yang tinggi dan kandungan bahan organik yang rendah serta mempunyai topsoil yang tipis $(<15 \mathrm{~cm})$. Kendala lainnya adalah rendahnya kapasitas tukar kation (KTK), nitrogen, fosfor, kalium serta sangat peka terhadap erosi. Ketidaksediaan $\mathrm{P}$ dalam tanah tergolong rendah akibat fiksasi oleh ion $\mathrm{Al}$ dan Fe yang membentuk Al-P dan Fe-P. Usaha untuk meningkatkan produktivitas tanah Ultisol memerlukan sejumlah masukan dan tindakan pengelolaan yang tepat, salah satunya dengan cara menambahkan cadangan hara ke dalam tanah dengan pemberian bahan organik (Nursanti, 2008).

Bahan organik mempunyai peranan penting dalam kesuburan tanah, melalui pengaruhnya terhadap sifat fisik, kimia dan biologi tanah. Bahan organik dapat berfungsi dalam memperbaiki struktur tanah, sebagai penyedia unsur hara seperti $\mathrm{N}, \mathrm{P}, \mathrm{K}, \mathrm{S}$ bagi tanaman, sebagai penyangga (buffer) terhadap perubahan $\mathrm{pH}$, dapat mengikat logam-logam dalam tanah, berkombinasi dengan mineral liat, dan meningkatkan kapasitas tukar kation dan sebagai energi bagi organisme tanah (Mulyadi, 2008). Aplikasi bahan organik dapat dilakukan dalam bentuk segar berupa pupuk hijau maupun kompos (Parnata, 2010).

Mikoriza mempunyai potensi untuk memperbaiki kualitas tanah Ultisol dengan memperbaiki ketersediaan hara bagi tanaman dilahan tersebut (Prihastuti, 2007), selain itu mikoriza berkontribusi hingga 90\% dari kebutuhan hara $\mathrm{P}$ tanaman (Van der Heijden et al., 2006) dan asosiasi mikoriza mampu meningkatkan ketahanan tanaman terhadap cekaman biotik (penyakit) dan abiotik (kekeringan) (Auge, 2001).

Dalam rangka memperbaiki serta meningkatkan kesuburan tanah, kompos merupakan bahan terbaik walaupun dalam prosesnya memerlukan waktu. Pemberian kompos ke dalam tanah secara berkelanjutan dapat memperbaiki sifat dan karakteristik tanah secara umum. Tersedianya kompos didalam tanah, tidak hanya menambah unsur hara makro, tetapi juga memperbaiki struktur tanah sehingga mampu mempertahankan kelembaban dan melancarkan sirkulasi udara dalam tanah, membantu dalam proses ionisasi melalui peningkatan kapasitas tukar kation, sehingga akar tanaman mampu mengambil hara dalam tanah. Selain itu, jasadjasad renik tanah mendapat energi dari kompos sehingga aktivitasnya meningkat dalam memperbaiki sifat biologi tanah (Atmojo, 2003). Berdasarkan uraian tersebut, maka perlu dilakukan penelitian tentang uji fungi mikoriza arbuskular spesifik lokal dan kompos untuk meningkatkan hasil tanaman jagung pada tanah marginal Ultisol.

\section{METODE PENELITIAN}

Penelitian ini dilaksanakan di Rumah Kasa Fakultas Pertanian Universitas Syiah Kuala dan Laboratorium Penelitian Tanah dan Tanaman serta Laboratorium Penyakit Tanaman Fakultas Pertanian Universitas Syiah Kuala, pada bulan Juni sampai Oktober 2016. 


\section{MATERI DAN METODE}

Benih jagung varietas Pertiwi-2, inokulum fungi mikoriza arbuskular yang telah diperbanyak, tanah Ultisol, kompos 5 ton ha ${ }^{-1}\left(25 \mathrm{~g} \mathrm{pot}^{-1}\right)$ dan 10 ton ha $\mathrm{ha}^{-1}\left(50 \mathrm{~g} \mathrm{pot}^{-1}\right)$, Urea $400 \mathrm{~kg} \mathrm{ha}^{-1}\left(2 \mathrm{~g} \mathrm{pot}^{-1}\right), \mathrm{SP}-36150 \mathrm{~kg} \mathrm{ha}^{-1}\left(1,39 \mathrm{~g} \mathrm{pot}^{-1}\right)$ dan $\mathrm{KCl} 75 \mathrm{~kg} \mathrm{ha}^{-1}\left(0,62 \mathrm{~g} \mathrm{pot}^{-1}\right)$, pot volume $10 \mathrm{~kg}$, larutan $\mathrm{KOH} \mathrm{10 \% ,} \mathrm{larutan} \mathrm{pemutih,} \mathrm{asam} \mathrm{cuka,} \mathrm{aquades,} \mathrm{tinta} \mathrm{quink,}$ timbangan duduk, timbangan analitik, meteran, oven, kertas label, jangka sorong, ayakan, handsprayer, botol pot, mikroskop, kaca preparat, kamera dan alat tulis.

\section{Metode Penelitian}

\section{Persiapan Media Tanam}

Media tanam yang digunakan dalam penelitian ini adalah bahan tanah Ultisol yang diambil dari Jantho, Aceh Besar. Sebelum digunakan tanah dikering anginkan terlebih dahulu kemudian dimasukkan ke dalam pot berukuran $10 \mathrm{~kg}$. Pot yang diperlukan sebanyak 54 pot.

\section{Persiapan Benih dan Penanaman}

Benih yang digunakan dalam penelitian ini adalah benih jagung varietas Pertiwi-2. Kebutuhan benih yang diperlukan sebanyak 108 benih. Tanah ditugal sedalam $2 \mathrm{~cm}$ kemudian benih jagung ditanam sebanyak dua benih per lubang.

\section{Aplikasi Kompos}

Kompos diayak terlebih dahulu sebelum digunakan. Untuk perlakuan yang menggunakan kompos, kompos dicampur rata dengan tanah Ultisol dengan menggunakan dua taraf perlakuan yaitu $25 \mathrm{~g} \mathrm{pot}^{-1}$ dan $50 \mathrm{~g} \mathrm{pot}^{-1}$.

\section{Pemberian Fungi Mikoriza Arbuskular}

Pemberian FMA dilakukan bersamaan pada saat benih ditanam. Pada saat benih diberikan FMA harus mengenai permukaan benih. Kebutuhan FMA sebanyak 20 g per lubang tanam.

\section{Pemupukan}

Aplikasi pupuk dasar dilakukan pada saat penanaman benih jagung. Dosis anjuran pupuk dasar tanaman jagung adalah Urea $400 \mathrm{~kg} \mathrm{ha}^{-1}\left(2 \mathrm{~g} \mathrm{pot}^{-1}\right)$, SP-36 $150 \mathrm{~kg} \mathrm{ha}^{-1}(1,39 \mathrm{~g}$ pot $\left.^{-1}\right)$ dan $\mathrm{KCl} 75 \mathrm{~kg} \mathrm{ha}^{1}\left(0,62 \mathrm{~g} \mathrm{pot}^{-1}\right)$. Pemupukan susulan dilakukan pada saat $20 \mathrm{HST}$ dengan memberikan Urea sebanyak $125 \mathrm{~kg} \mathrm{ha}^{-1}\left(0,6 \mathrm{~g} \mathrm{pot}^{-1}\right)$ dan pada saat $35 \mathrm{HST}$ dengan memberikan Urea sebanyak $125 \mathrm{~kg} \mathrm{ha}^{-1}\left(0,6 \mathrm{~g} \mathrm{pot}^{-1}\right)$.

\section{Pemeliharaan Tanaman}

Pemeliharaan tanaman yang dilakukan terdiri dari penyiraman, penyulaman, penyiangan dan pengendalian hama penyakit tanaman. Penyiraman dilakukan dua kali sehari yaitu pada pagi dan sore hari. Penyulaman dilakukan apabila tanaman yang ditanam tidak tumbuh. Penyiangan dilakukan dengan membersihkan gulma yang ada disekitar areal pertanaman. Pembumbunan dilakukan bersamaan dengan penyiangan agar tanaman tidak mudah rebah. Pengendalian hama dan penyakit dilakukan pada saat tanaman terserang hama dan penyakit dengan menyemprotkan insektisida Decis-1 dengan dosis 0,2 $\mathrm{ml}$.

\section{Pemanenan}

Pemanenan dilakukan pada saat tanaman berumur 101 HST. Kriteria panen buah jagung antara lain: kondisi daun tetap hijau walau tanaman sudah siap panen, rambut jagung telah berwarna merah kecokelatan. 


\section{Pengamatan}

Adapun pengubah yang diamati adalah :

\section{Jumlah Biji per Kelobot (butir)}

Pengamatan dilakukan dengan cara menghitung jumlah biji tiap kelobot dari masingmasing tanaman sampel.

\section{Berat Biji Kering per Buah (g)}

Pengamatan dilakukan setelah panen dengan cara menimbang buah jagung yang telah dikeringkan.

\section{Berat 100 Butir Biji Kering (g)}

Berat 100 butir biji ditimbang dengan menggunakan timbangan analitik yang diperoleh dari setiap sampel tanaman.

\section{Hasil per Hektar (ton ha ${ }^{-1}$ )}

Pengamatan produksi per ha dilakukan dengan mengkonversikan rata-rata berat tongkol tanpa kelobot dengan rumus sebagai berikut :

$$
\text { Potensi hasil }\left(\operatorname{ton}^{-1}\right)=\frac{\text { luas tanah } 1 \text { hektar }}{\text { jarak tanam }} \times \text { hasil } / \text { tanaman }
$$

\section{Analisis Statistik}

Penelitian ini menggunakan Rancangan Acak Kelompok (RAK) pola faktorial 3x3 dengan tiga ulangan dan terdapat dua faktor yang diteliti. Faktor pertama pemberian jenis FMA (M) yang terdiri dari : $\mathrm{M}_{0}$ (Tanpa mikoriza), $\mathrm{M}_{2}$ (Glomus sp.), $\mathrm{M}_{3}$ (Acolouspora sp.). Faktor kedua dosis kompos $(\mathrm{K})$ dengan menggunakan 3 taraf yaitu: $\mathrm{K}_{0}$ : Tanpa Kompos, $\mathrm{K}_{1}$ (dosis kompos $25 \mathrm{~g} \mathrm{pot}^{-1}$ ), $\mathrm{K}_{2}$ (dosis kompos $50 \mathrm{~g} \mathrm{pot}^{-1}$ ). Dengan demikian, terdapat 9 kombinasi perlakuan dengan 3 kali ulangan sehingga diperoleh 27 satuan percobaan.

\section{HASIL DAN PEMBAHASAN}

\section{Pengaruh Pemberian Jenis FMA terhadap Hasil Tanaman Jagung}

Berdasarkan hasil analisis ragam uji $\mathrm{F}$ menunjukkan bahwa perlakuan pemberian jenis mikoriza arbuskular (FMA) tidak berpengaruh nyata jumlah biji per tongkol, berat biji per tongkol, berat 100 butir biji kering dan hasil per hektar.

Hal ini diduga karena tidak terdapat asosiasi antara mikoriza dengan inangnya. Penyebab tidak terjadinya asosiasi mikoriza dengan inangnya adalah karena FMA yang diinokulasikan belum mampu mengeksplorasi akar ke permukaan tanah dan belum mampu mempercepat gerakan-gerakan ion tanah. Besarnya tingkat infeksi mikoriza tidak berarti menunjukkan pengaruh positif terhadap pertumbuhan inang atau dengan kata lain mampu meningkatkan pertumbuhan inang, karena besarnya kolonisasi akar bisa saja tidak menghasilkan atau tidak meningkatkan produksi spora. Menurut Chalimah et al., (2007), kondisi inokulum yang dimaksud adalah infektivitas dan efektivitas inokulum yang selalu memberikan respon berbeda terhadap pertumbuhan inang. Infektivitas adalah jumlah akar tanaman yang terinfeksi oleh FMA tanpa melihat kemampuan menginfeksi dan penyebaran hifa jenis lain. Infektivitas sangat bergantung pada jumlah inokulum atau kepadatan inokulum 
dan penempatan inokulum. Spesies FMA juga mempunyai perbedaan dalam kemampuannya meningkatkan penyerapan hara dan pertumbuhan tanaman. Lingkungan dan tempat tumbuh merupakan hal yang mempengaruhi perkecambahan spora dan kolonisasi FMA. Fungi mikoriza arbuskula pada dasarnya tidak memilih inang spesifik, namun daya infeksi, serta efektivitas FMA berbeda pada setiap inang (Chalimah et al., 2007). Rata-rata hasil tanaman jagung akibat perlakuan dosis mikoriza setelah di uji dengan BNJ 0,05 dapat dilihat pada Tabel 1 .

Tabel 1. Rata-rata nilai potensi hasil tanaman jagung akibat perlakuan pemberian jenis FMA

\begin{tabular}{|c|c|c|c|c|}
\hline \multirow[b]{2}{*}{ Parameter yang di amati } & \multicolumn{3}{|c|}{ Jenis FMA } & \multirow[b]{2}{*}{$\begin{array}{c}\text { BNJ } \\
0,05 \%\end{array}$} \\
\hline & $\begin{array}{c}\text { Tanpa } \\
\text { Mikoriza }\left(\mathrm{M}_{0}\right)\end{array}$ & $\begin{array}{c}\text { Glomus } \\
\text { sp. } \\
\left(\mathrm{M}_{1}\right)\end{array}$ & $\begin{array}{c}\text { Acoulospora } \\
\text { sp. }\left(\mathrm{M}_{2}\right)\end{array}$ & \\
\hline Jumlah Biji (butir) & 333.33 & 432.66 & 311.22 & - \\
\hline Berat Biji Kering $(\mathrm{g})$ & 79.16 & 94.85 & 70.54 & - \\
\hline Berat 100 Butir $(\mathrm{g})$ & 25.25 & 23.80 & 27.54 & - \\
\hline Hasil per ha(ton $\mathrm{ha}^{-1}$ ) & 5.28 & 6.29 & 4.61 & - \\
\hline
\end{tabular}

\section{Pengaruh Dosis Kompos terhadap Hasil Tanaman Jagung}

Hasil analisis ragam uji $\mathrm{F}$ menunjukkan bahwa perlakuan dosis kompos tidak berpengaruh nyata terhadap parameter jumlah biji per tongkol, berat biji kering per tongkol, berat 100 butir biji kering dan hasil per hektar. Rata-rata hasil tanaman jagung akibat perlakuan dosis mikoriza setelah di uji dengan BNJ 0,05 dapat dilihat pada Tabel 2.

Tabel 2. Rata-rata nilai potensi hasil tanaman jagung akibat perlakuan pemberian dosis kompos

\begin{tabular}{lcccc}
\hline \multirow{2}{*}{ Parameter yang di amati } & \multicolumn{3}{c}{ Dosis Kompos } & \multirow{2}{*}{ BNJ } \\
\cline { 2 - 4 } & $\begin{array}{c}\text { Tanpa } \\
\text { Kompos }\left(\mathrm{K}_{0}\right)\end{array}$ & $\begin{array}{c}25 \mathrm{~g} \mathrm{pot}^{-1} \\
\left(\mathrm{~K}_{1}\right)\end{array}$ & $\begin{array}{c}50 \mathrm{~g} \mathrm{pot}^{-1} \\
\left(\mathrm{~K}_{2}\right)\end{array}$ & $0,05 \%$ \\
\hline Jumlah Biji (butir) & 358.22 & 358.55 & 360.44 & - \\
\hline Berat Biji Kering (g) & 87.43 & 85.77 & 71.35 & - \\
\hline Berat 100 Butir (g) & 24.21 & 28.49 & 23.90 & - \\
\hline Hasil per ha(ton ha $\left.{ }^{-1}\right)$ & 5.80 & 5.71 & 4.66 & - \\
\hline Keterangan $\quad \begin{array}{l}\text { Angka yang diikuti oleh huruf yang sama pada kolom yang sama berbeda tidak nyata pada } \\
\text { taraf 0.05 (Uji BNJ). }\end{array}$ & $\begin{array}{l}\text { Hal ini diduga karena pemberian kompos belum sepenuhnya terurai sempurna } \\
\text { sehingga tanaman sulit menyerap hara yang terdapat dalam tanah. Sejalan dengan pernyataan } \\
\text { Sutedjo (2002) dalam Iskandar (2003) yang menyatakan bahwa tanaman tidak akan }\end{array}$
\end{tabular}


memberikan hasil yang maksimal apabila unsur hara yang diperlukan tidak tersedia. Berdasarkan penjelasan tersebut hal ini sejalan dengan pernyataan Lingga dan Marsono (2007) bahwa pemberian pupuk dengan konsentrasi yang berlebihan atau kekurangan dapat merugikan tanaman, dosis yang tepat mampu memperbaiki dan meningkatkan pertumbuhan tanaman.

\section{Interaksi antara Fungi Mikoriza Arbuskular Spesisik Lokal dan Kompos Terhadap Hasil Tanaman Jagung}

\section{a. Berat Biji Kering per Tongkol}

Rata-rata berat biji kering per tongkol akibat kombinasi perlakuan pemberian jenis FMA dan dosis kompos dapat dilihat pada Tabel 3.

Tabel 3. Rata-rata berat biji kering per tongkol akibat kombinasi pemberian jenis FMA dan dosis kompos

\begin{tabular}{|c|c|c|c|c|}
\hline \multirow[b]{2}{*}{ Jenis FMA } & \multicolumn{3}{|c|}{ Dosis Kompos } & \multirow[b]{2}{*}{$\mathrm{BNJ}_{0,05}$} \\
\hline & $\begin{array}{c}\text { Tanpa Kompos } \\
\left(\mathrm{K}_{0}\right)\end{array}$ & $25 \operatorname{g~pot}_{\left(K_{1}\right)}^{-1}$ & $\begin{array}{c}50 \mathrm{~g} \mathrm{pot}^{-1} \\
\left(\mathrm{~K}_{2}\right)\end{array}$ & \\
\hline Tanpa Mikoriza $\left(\mathrm{M}_{0}\right)$ & $112.04 \mathrm{~B}$ & $59.92 \mathrm{~A}$ & $65.54 \mathrm{~A}$ & \\
\hline Glomus sp. & $\begin{array}{c}\mathrm{b} \\
88.85 \mathrm{AB} \\
\mathrm{ab}\end{array}$ & $\begin{array}{c}a \\
131.69 \mathrm{~B} \\
\mathrm{~b}\end{array}$ & $\begin{array}{c}\mathrm{a} \\
64.03 \mathrm{~A} \\
\mathrm{a}\end{array}$ & \\
\hline Acoulospora sp. $\left(\mathrm{M}_{2}\right)$ & $\begin{array}{c}61.40 \mathrm{~A} \\
\mathrm{a}\end{array}$ & $\begin{array}{c}65.73 \mathrm{~A} \\
\mathrm{a}\end{array}$ & $\begin{array}{c}84.50 \mathrm{~A} \\
\mathrm{a}\end{array}$ & \\
\hline $\mathrm{BNJ}_{0,05}$ & & & & 49.41 \\
\hline
\end{tabular}

Keterangan : Angka-angka yang diikuti oleh huruf yang sama pada kolom yang sama menunjukkan berbeda tidak nyata pada taraf peluang BNJ 5\%. Huruf kapital merupakan notasi pada baris, huruf kecil merupakan notasi pada kolom.

Tabel 3 menunjukkan bahwa berat biji kering per tongkol lebih tinggi dijumpai pada kombinasi perlakuan Glomus sp. $\left(\mathrm{M}_{1}\right)$ dengan dosis kompos $25 \mathrm{~g} \operatorname{pot}^{-1}\left(\mathrm{~K}_{1}\right)$ yang tidak berbeda nyata dengan kombinasi perlakuan tanpa mikoriza $\left(\mathrm{M}_{0}\right)$ dan dosis tanpa kompos $\left(\mathrm{K}_{0}\right)$ namun berbeda nyata dengan kombinasi perlakuan lainnya. Rata-rata berat biji kering per tongkol akibat interaksi perlakuan pemberian jenis FMA dan dosis kompos dapat dilihat pada Gambar 1.

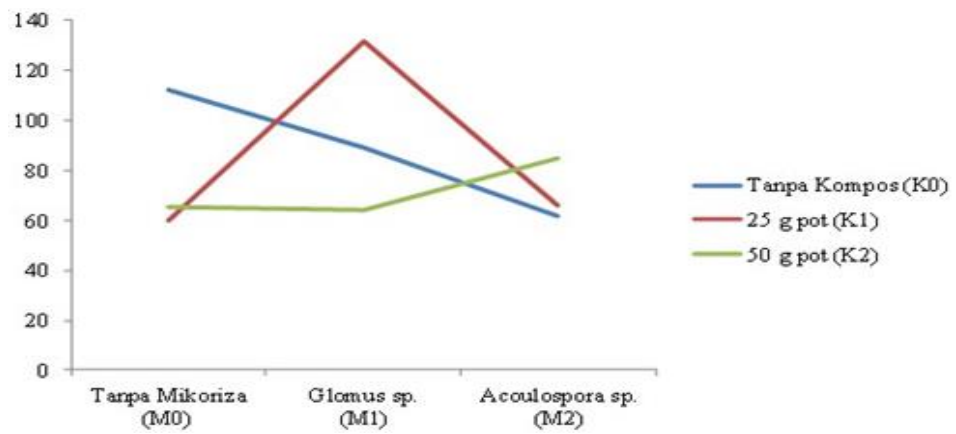

Gambar 3. Rata-rata berat biji kering per tongkol akibat kombinasi perlakuan pemberian jenis FMA dan dosis kompos 
Hasil penelitian Budiman (2004) menyatakan bahwa tersedianya unsur hara yang cukup pada saat pertumbuhan menyebabkan metabolisme tanaman akan lebih aktif sehingga proses pemanjangan pembelahan dan differensiasi sel akan lebih baik yang akhirnya akan mendorong peningkatan berat buah. Tersedianya unsur $\mathrm{P}$ menyebabkan fotosintat yang dialokasikan ke buah menjadi lebih sehingga ukuran buah lebih besar. Adanya peran mikoriza dapat meningkatkan berat biji kering buah.

\section{b. Hasil per Hektar}

Rata-rata hasil per hektar akibat kombinasi perlakuan pemberian jenis FMA dan dosis kompos dapat dilihat pada Tabel 4.

Tabel 4. Rata-rata hasil per hektar akibat kombinasi pemberian jenis FMA dan dosis kompos

\begin{tabular}{|c|c|c|c|c|}
\hline \multirow[b]{2}{*}{ Jenis FMA } & \multicolumn{3}{|c|}{ Dosis Kompos } & \multirow[b]{2}{*}{$\mathrm{BNJ}_{0,05}$} \\
\hline & $\begin{array}{c}\text { Tanpa Kompos } \\
\left(\mathrm{K}_{0}\right)\end{array}$ & $25 \mathrm{~g} \operatorname{pot}\left(\mathrm{K}_{1}\right)$ & $50 \mathrm{~g} \operatorname{pot}\left(\mathrm{K}_{2}\right)$ & \\
\hline \multirow{2}{*}{ Tanpa Mikoriza $\left(\mathrm{M}_{0}\right)$} & $7.48 \quad \mathrm{~B}$ & $3.99 \mathrm{~A}$ & $4.37 \mathrm{~A}$ & \\
\hline & $\mathrm{b}$ & $\mathrm{a}$ & $\mathrm{ab}$ & \\
\hline \multirow{2}{*}{ Glomus sp. $\quad\left(\mathrm{M}_{1}\right)$} & $5.85 \mathrm{AB}$ & $8.77 \mathrm{~B}$ & $4.26 \mathrm{~A}$ & \\
\hline & $a b$ & $\mathrm{~b}$ & $\mathrm{a}$ & \\
\hline \multirow{2}{*}{ Acoulospora sp. $\left(\mathrm{M}_{2}\right)$} & $4.09 \mathrm{~A}$ & $4.38 \mathrm{~A}$ & $5.37 \mathrm{~A}$ & \\
\hline & $\mathrm{a}$ & $\mathrm{a}$ & $\mathrm{a}$ & \\
\hline
\end{tabular}

Keterangan : Angka-angka yang diikuti oleh huruf yang sama pada kolom yang sama menunjukkan berbeda tidak nyata pada taraf peluang BNJ 5\%. Huruf kapital merupakan notasi pada baris, huruf kecil merupakan notasi pada kolom.

Tabel 4 menunjukkan bahwa hasil per hektar lebih tinggi dijumpai pada kombinasi perlakuan Glomus sp. $\left(\mathrm{M}_{1}\right)$ dengan dosis kompos $25 \mathrm{~g} \mathrm{pot}^{-1}\left(\mathrm{~K}_{1}\right)$ yang tidak berbeda nyata dengan kombinasi perlakuan tanpa mikoriza $\left(\mathrm{M}_{0}\right)$ dan dosis tanpa kompos $\left(\mathrm{K}_{0}\right)$, namun berbeda nyata dengan kombinasi perlakuan lainnya. Rata-rata hasil per hektar akibat interaksi perlakuan pemberian jenis FMA dan dosis kompos dapat dilihat pada Gambar 4.

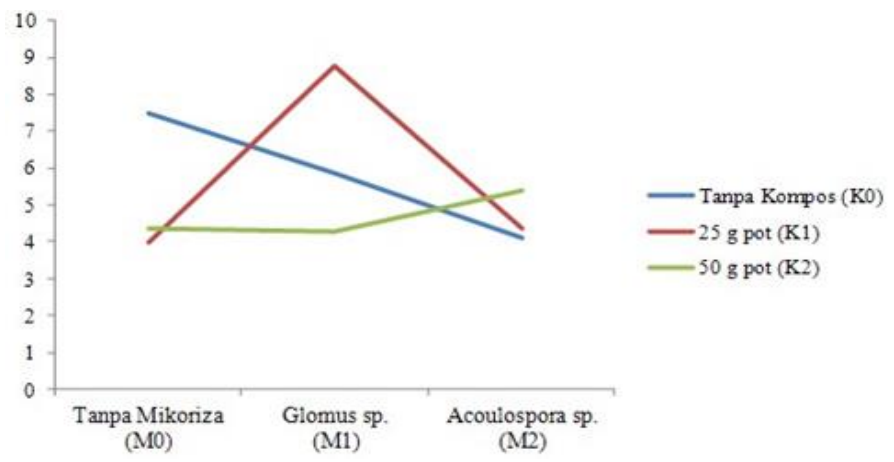

Gambar 4. Rata-rata hasil per hektar akibat kombinasi perlakuan pemberian jenis FMA dan dosis kompos

Jagung dipetik dalam bentuk tongkol berkelobot, sehingga dalam hal ini yang berperan menentukan hasil tanaman adalah besarnya fotosintat yang terdapat pada daun dan 
batang. Apabila transport fotosintat dari kedua organ ini dapat ditingkatkan selama fase pengisian biji maka hasil tanaman yang berupa biji dapat ditingkatkan. Terpenuhinya kebutuhan unsur hara, cahaya dan air menjadikan hasil fotosintesis akan terbentuk dengan baik.

\section{SIMPULAN DAN SARAN}

Pertumbuhan dan hasil tanaman jagung lebih baik dijumpai pada jenis mikoriza Glomus sp. Pada dosis kompos lebih baik dijumpai pada dosis $50 \mathrm{~g} \mathrm{pot}^{-1}$ serta terdapat interaksi yang nyata antara perlakuan jenis FMA dengan dosis kompos terhadap pertumbuhan dan hasil tanaman jagung. Kombinasi perlakuan terbaik dijumpai pada Glomus sp. dengan dosis kompos $25 \mathrm{~g} \mathrm{pot}^{-1}$.

Perlu dilakukan penelitian lanjutan terhadap pengaruh mikoriza dengan menambahkan berbagai jenis mikoriza lainnya.

\section{DAFTAR PUSTAKA}

Atmojo, S.W. 2003. Peranan bahan organik terhadap kesuburan tanah dan upaya pengelolaannya. Sebelas Maret University Press. Surakarta. $36 \mathrm{hlm}$.

Auge, R.M. 2001. Water Realations, Drought and Versicular Arbuscular Mychorrhizal Symbiosis. J. Mychorrhiza 11:3:42.

Biro Pusat Statistik. 2016. Aceh dalam Angka 2015. Banda Aceh.

Budiman, A. 2004. Aplikasi kascing dan cendawan mikoriza arbuskula (CMA) pada Ultisol serta efeknya terhadap perkembangan mikroorganisme tanah dan hasil tanaman jagung semi (Zea mays L.). Skripsi. Fakultas Pertanian Universitas Andalas, Padang.

Chalimah, S., Muhadiono, Aznam, L., Haran, S. dan T.M Nurita. 2007. Perbanyakan Gigaspora sp dan Acaulospora sp dengan kultur pot di rumah kaca. Disertasi.Institut Pertanian Bogor. Bogor.

Foth, H.D. 1991. Dasar-dasar Ilmu Tanah. Gadjah Mada University Press, Yogyakarta.

Iskandar, D. 2003. Pengaruh dosis pupuk N, P, K terhadap pertumbuhan dan produksi jagung manis di lahan kering. Prosiding. Seminar Teknologi untuk Negeri 2003, Vol. II, Hal. 15/HUMAS-BPPT/ANY.

Mimbar, S.M. 1990. Pola pertumbuhan dan hasil jagung kretek karena pengaruh pupuk N. J. Agrivita. 13 (3) : 82-89.

Mulyadi, A. 2008. Karakteristik kompos dan bahan tanaman kaliandra, jerami padi dan sampah sayuran. Skripsi. Program Studi Ilmu Tanah. Fakultas Pertanian. Institut Pertanian Bogor. Bogor.

Nursanti. 2008. Pemanfaatan pupuk bio-organik terhadap beberapa sifat kimia Ultisol dan populasi mikroba rhizosfer serta hasil cabai (Capsicum annum). J. Agronomi. 12: 7-9.

Parnata S.A. 2010. Meningkatkan Hasil Panen dengan Pupuk Organik. Agromedia Pustaka. Jakarta. 